\title{
Chapter 12 \\ Kindergarten to Grade 12 Reforms in Viet Nam
}

\author{
Ron Cammaert, Thi Phuoc Lai Nguyen, and Sakiko Tanaka
}

Viet Nam has evolved from one of the world's poorest countries in the 1990s to a lower middle-income country with a per capita income of $\$ 2,111$ in 2015-more than 20 times larger than that in 1990 (\$98). ${ }^{1}$ To make the most of its middle-income stage of development and to avoid being perpetually trapped there, Viet Nam will need to create productive job opportunities, support intermediate technology, and promote research and development and innovation. Ranked 77th out of 140 countries on the Global Competitiveness Index 2018, Viet Nam's labor productivity levels are lower than other countries in the region. ${ }^{2}$ A shortage of skills and gaps in the labor force is affecting the country's ability to absorb new foreign investment and limiting prospects for expanding productive employment (only $21.5 \%$ of the employed labor force has qualified skills- $24.1 \%$ of men and $18.8 \%$ of women). ${ }^{3}$ The education system needs to be reformed to give students equitable access to relevant skills.

\footnotetext{
${ }^{1}$ World Development Indicators, World Bank, http://data.worldbank.org/country/vietnam (accessed 24 April 2017).

${ }^{2}$ World Economic Forum. 2018. Global Competitiveness Report 2017-2018. Switzerland.

${ }^{3}$ General Statistics Office (GSO). 2017. Labor Force Survey Q1 2017. Ha Noi.
}

The contents were extracted from the forthcoming ADB report on Viet Nam Secondary Education Sector Assessment, Strategy and Roadmap, and combined with the information from ADB Loan VIE 3494/3493 Second Secondary Education Sector Development Program (SESDP II).

\section{R. Cammaert}

Education Consultant, Manila, Philippines

T. P. L. Nguyen

STEM Consultant, Manila, Philippines

\section{S. Tanaka (凶)}

Southeast Asia Department, Principal Social Sector Specialist, Asian Development Bank, Manila, Philippines

e-mail: sakikotanaka@adb.org 
The Government's high priority on education has resulted in new teacher standards, student-centered teaching, a new school accreditation agency, and expanded learning opportunities for disadvantaged youth. The 2012 and 2015 results from the Programme for International Student Assessment (PISA) showed that Vietnamese students are internationally competitive. ${ }^{4,5}$ The Socio-economic Development Plan 2016-2020 also indicates that the education sector performed well over the period 2011-2015. However, every Sustainable Development Goal requires education to empower people with the knowledge, skills, and values to build their lives and contribute to society. Science, Technology, Engineering, and Mathematics (STEM) education appears relevant and essential for preparing the young generation.

\section{Issues and Challenges}

Net Enrollment Rates Have Yet to Be Realized. The general education system consists of preprimary programs catering to 3-5-year-old students; a 5-year program of primary education for students starting at six years of age; Lower Secondary Education (LSE) covering grades 6-9 for 11-14-year-old students; and Upper Secondary Education (USE) for grades 10-12. Viet Nam's birth rate has been declining, which is reflected in the dip in the total number of students in the education system around School Year (SY) 2008/09. Enrollments in preprimary and primary have increased in the last five years, but enrollments in LSE and USE are still lower than historic highs. In SY2015/16, about 7.79 million students were enrolled in primary (3.74 million girls), 5.14 million in LSE (2.51 million girls), and 2.43 million in USE (1.30 million girls). In SY2015/16, universal primary education was achieved with a Net Enrollment Rate (NER) of 99\%. However, the Government's targets of achieving an NER for LSE of 95 and $80 \%$ for USE have not yet been realized (in SY2015/16, LSE was at $92.3 \%$ and USE at $63.0 \%)^{6}$

\section{Quality of Secondary Education Remains Weak and Not Relevant to Labor}

Market. As the economy becomes modernized and industrialized, the challenge is to produce graduates and school leavers who are technically skilled and able to critically analyze and solve problems. Although Viet Nam's results for PISA 2012 and 2015 were at or above the international average, the results for mathematics and reading declined from 2012 to 2015, were lower than neighboring economic

\footnotetext{
${ }^{4}$ OECD. 2016. PISA 2015 Results (Volume I): Excellence and Equity in Education, OECD Publishing, Paris.

${ }^{5}$ On the 2015 PISA assessment, the performance of boys and girls was not significantly different for mathematics and science, but as in all OECD countries girls outperformed boys in reading.

${ }^{6}$ National data is from Education Statistics Yearbook 2015-2016. Ha Noi and gender data are from Household Living Standards Survey 2014; the NER in LSE for boys was $83.8 \%$ and for girls was $85.1 \%$; at the USE level, the NER for boys was $58.2 \%$ and for girls was $68.3 \%$. While overall NER in LSE and USE is higher for girls, gender disparities in access and achievement remain an issue for certain regions and provinces, and for certain groups.
} 
competitors, and had few high-performing students. ${ }^{7}$ Having a low percentage of students performing at the top levels signals the absence of a highly educated talent pool for the future. Viet Nam's high performance could also reflect rote learning and proficient test-taking skills, rather than the ability to use knowledge in new situations. ${ }^{8}$ The National Achievement Monitoring (NAM) test results show a decline at the grade 9 level in all subjects and a decrease in mathematics at grade 11. NAM results indicate that only $46.7 \%$ of grade 9 students passed the national 2012/2013 mathematics assessment (boys at $46.7 \%$ and girls equal at $46.6 \%$ ), while only $52.2 \%$ of grade 11 students passed the 2014/2015 mathematics assessment (boys at $48.0 \%$ and girls significantly higher at $55.8 \%$ ), and only $40.4 \%$ of grade 11 students passed English (boys at $38.5 \%$ and girls at $45.2 \%)^{9}$

\section{Secondary Education Does Not Provide Students with Skills to Succeed in the}

Workplace The present curriculum was designed to be broader in scope and relevant to labor market needs. ${ }^{10}$ New textbooks were developed, and teachers received extensive training on new approaches to learning and teaching. Despite these efforts, a 2010 study by Viet Nam's National Institute of Education Sciences concluded that (i) the curriculum did not equip students with the knowledge and skills needed for future careers, and (ii) the low quality of secondary education constrained the development of a skilled labor force. ${ }^{11}$ For secondary education graduates-who enter the labor market immediately after graduation - and students who continue postsecondary education, jobs are difficult to find. Secondary education does not provide students with the cognitive, social, and behavioral foundation skills that are critical to succeeding in the workplace. The returns to education for LSE and USE graduates were only 1.2 and 1.5 larger than those of primary education graduates, respectively, while college and university graduates earn 2.4 times more than primary graduates and 1.8 times more than USE graduates. ${ }^{12}$

High Percentage of the Population Not Obtaining Secondary Education. Because too many young people are not receiving enough education, Viet Nam cannot move forward economically and socially. In SY2015/16, about 430,000 youths (240,250 boys and 189,750 girls) of LSE age were not enrolled in the school system. At the USE level, more than 1.4 million youths (821,400 boys and 602,600 girls) were not enrolled. Having such a high percentage of the population not obtaining secondary

\footnotetext{
${ }^{7}$ OECD. 2016. PISA 2015 Results (Volume I): Excellence and Equity in Education, OECD Publishing, Paris.

${ }^{8}$ University of Oxford, Young Lives. 2017. Thinking outside the box: Do students in Vietnam have 21 st century skills? https://www.younglives.org.uk/content/thinking-outside-box-do-studentsvietnam-have-21st-century-skills (accessed 11 September 2017).

${ }^{9}$ Government of Viet Nam, Ministry of Education and Training, Center of Education Quality Assurance. 2016. Results from the National Achievement Monitoring. Ha Noi.

${ }^{10}$ ADB. 2011. Project Completion Report: Upper Secondary Education Development Project in Viet Nam. Manila.

${ }^{11}$ Viet Nam National Institute of Education Sciences. 2010. Assessment of Quality of Upper Secondary Curriculum and Textbooks. Ha Noi.

${ }^{12}$ Source: Labor Force Survey. 2014.
} 
education represents a significant loss to the economy. ${ }^{13}$ Lack of access to and poor quality of secondary education affect the labor force. ${ }^{14}$ Despite the Government's continued efforts to increase access to education and retain school students from vulnerable groups, including ethnic minorities, disabled, and girls living in the Northern Midland and Mountainous regions, inequality in educational access and quality persists, especially among boys and girls from ethnic minority groups and various geographic regions.

Educational Opportunities for Ethnic Minority and Children with Disabilities Still Restricted. In addition to not being able to take advantage of access to education, ethnic minority students who are in school achieve considerably lower than those in the majority. There have been few targeted interventions for youth with disabilities. According to the 2009 Viet Nam Population and Household Census, around $7.8 \%$ (7.1\% of males and $8.5 \%$ of females) of the population of 5-years-old and older live with one or more physical or mental disabilities. However, in SY2013/14, only 13,572 students with a disability attended LSE, which is $0.3 \%$ of the student population at this level, and 1,520 or $0.1 \%$ of students at USE. ${ }^{15,16}$ While the Government has provided financial support programs to the disabled, education opportunities for these children remain restricted with fewer opportunities for employment and integration.

\section{Proposed Solutions}

Government Committed to Enhancing Educational Quality. The policy framework for the long-term development of education is defined by (i) the Socio-economic Development Strategy, 2011-2020; (ii) the Education Development Strategy, 20112020; (iii) Resolution No. 29; (iv) Resolution No. 44; and (v) Decision No. 2653. ${ }^{17}$

\footnotetext{
${ }^{13}$ At both the LSE and USE levels, there are proportionally more boys than girls not attending school. Gender disparities exist between geographical regions, with a higher number of out-ofschool boys in the Central Highlands and a higher number of out-of-school girls in the Northern Midlands and Mountainous area (54.3\% of out-of-school children at USE were girls in that region). From UN Vietnam Gender Briefing kit 2016.

${ }^{14}$ General Statistics Office. Labor Force Survey Q1 2017. It defines “qualified skills" as workers with at least three months of vocational training, professional secondary, technical college, or university degree.

${ }^{15}$ Department of Planning and Finance, MOET. 2015. Ha Noi.

${ }^{16}$ According to the 2009 Viet Nam Population and Household Census, the ratio of girls to boys with a disability in school was about 0.7 , indicating a disproportionate number of girls are not attending school.

${ }^{17}$ Government of Viet Nam. 2010. Socio-Economic Development Strategy, 2011-2020. Ha Noi. Central Committee of the Communist Party of Viet Nam. 2013. Resolution No. 29-NQ/TW 8 on Comprehensive Innovations of Education and Training. Ha Noi. Government of Viet Nam. 2014. Prime Minister's Resolution No. 44/NQ-CP on Radical Changes in Education and Training. Ha Noi. Government of Viet Nam. MOET. 2014. Minister of Education Decision No: 2653/QD-BGDĐT Action Plan of the Education Sector for the Implementation of Resolution No. 29. H Ha Noi.
} 
The Government is committed to enhance education quality through comprehensive reforms that will foster integration of disadvantaged groups in education and competitiveness in the labor market and is committed to achieving the United Nations' Sustainable Development Goals (SDGs) and to achieve gender equality through the Action Plan on Gender Equality of the Education Sector for 2016-2020. ${ }^{18}$

Education reforms Are Being Planned. The Ministry of Education and Training (MOET) approved a new curriculum in December 2018 to achieve the desired renovation of the education system through (i) simplify and modernize the curriculum to better address labor market requirements; (ii) have teaching and learning methods that encourage the learners' independence, creativity, and application of knowledge; (iii) ensure that textbooks, teaching, and learning materials suit the needs of corresponding learners, remove gender stereotypes, and promote positive attitudes to ethnic minorities or those who are disabled; (iv) establish examinations and classroom assessments that measure the desired student competencies; (v) equip educators by changing the aims, content, methods of training, retraining, and evaluation of teachers and management officials; (vi) ensure that students receive career guidance; (vii) have local education administration agencies participate in decisions on personnel, finance, and administration; (viii) strengthen gender mainstreaming in education; and (ix) assess and disclose the quality of educational institutions throughout the country.

Government Targeting Spending $20 \%$ of Total Budget on Education and Training. In 2015, Viet Nam's expenditure on education and training was $15.3 \%$ of the total government budget, which is comparable to its middle-income neighbors and to the regional average of East Asia and the Pacific. At 5.5\% of gross domestic product, Viet Nam's public expenditure on education compares well with some of East Asia's wealthiest nations. The Government is targeting spending $20 \%$ of its total budget on education and training, signifying the importance of education as a strategy for human resource development. ${ }^{19}$ The Government has also made steady efforts to improve the efficiency of education expenditure. In 2015, it approved a revised State Budget Law, to address critical weaknesses in public financial management systems. This law introduced a 5-year medium-term expenditure framework and public investment plans that will allow for more strategic and disciplined expenditure planning, including for MOET.

\footnotetext{
${ }^{18}$ United Nations. 2015. Transforming Our World: The 2030 Agenda for Sustainable Development. New York. Goal 4 specifically addresses education, but education is a major strategy for many of the goals related to poverty reduction.

${ }^{19}$ Government of Viet Nam. 2012. Education Development Strategy, 2011-2020. Ha Noi.
} 


\section{Examples of Good Practices}

One of the reform areas in the new curriculum MOET emphasizes STEM education to improve the quality of education. STEM education is defined as "an interdisciplinary approach to learning where rigorous academic concepts are coupled with real-world lessons as students apply science, technology, engineering, and mathematics in contexts that make connections between school, community, work, and the global enterprise enabling the development of STEM literacy and with it the ability to compete in the new economy."20 It emphasizes the importance of making connections between academic knowledge and real-world problems as the foundation for integrating STEM subjects in teaching. Due to its interdisciplinary nature, STEM education is seen as both curricular and pedagogical approach. ${ }^{21}$ STEM education highlights the interdisciplinary framework, while in instructional practices, inquiry through representations, problem-solving/reasoning, challenge-based learning, design-based approaches, and digital technologies are the center of pedagogical approaches. The key of instructional practices of integrated STEM education in secondary schools is integration of STEM content, problem-centered learning, inquiry-based learning, design-based learning, and cooperative learning.

\section{Application of These Good Practices}

The Government of Viet Nam is aware of the need for investment in education for addressing the great social, economic, and environmental challenges of the country and ultimately for achieving the SDGs. Through Asian Development Bank loan support (ADB Loan 3494/3494-VIE), MOET has integrated STEM education into secondary schools through the Second Secondary Education Sector Development Program II (SESDP II). The objectives of STEM education setup by SESDP II are to (i) enhance comprehensive education for students; (ii) improve students' STEM literacy; (iii) develop students' soft and academic skills such as problem-solving, creativity, critical thinking, augmentation, intellectual curiosity, and collaboration skills; (iv) connect schools to communities; (v) orient students' career development; and (vi) prepare for Industry 4.0, which refers to the changes required by Industry to accommodate changes brought about by the Fourth Industrial Revolution.

SESDP II established an STEM research team at the national level, wherein research team members are from pedagogical universities of Viet Nam. Trainings on STEM concepts, integration frameworks, pedagogical approaches for teachers

\footnotetext{
${ }^{20}$ Tsupros, N., Kohler, R., and Hallinen, J. 2009. STEM Education: A Project to Identify the Missing Components. Pennsylvania.

${ }^{21}$ Margot, K. C. and Kettler, T. 2019. Teachers' perception of STEM integration and education: a systematic literature review. International Journal of STEM Education, 6(1), 2.
} 
of both lower and upper secondary schools as well as trainings on STEM education and its role in development for school managers and provincial/district educational policy makers/implementers are being implemented. In these trainings, STEM research team members have played the role of trainers with observers invited from several pedagogical universities in different regions of the country. The program encourages teachers to develop and plan their own STEM lessons or topics through project-based learning approaches and submit them to the STEM research team for review, revision, and improvement. Several best teachers' STEM lessons/topics have been selected and used as examples during the above-mentioned trainings. An online STEM education platform was established in September 2019. wherein all STEM scientific papers, reports, lecture notes, training handouts, and video clips of best STEM teaching lessons developed by teachers on the ground were uploaded for the use of all teachers in the country. ${ }^{22}$ This online platform is a resource for interactions, discussions, and feedback among teachers and researchers as well as a foundation for lifelong learning of teachers.

After three months of intensive STEM training activities, the program has received positive feedback and strong interest from teachers, school principals, and provincial education managers. Eighty-two STEM lessons have been voluntarily developed and submitted by teachers from lower and upper schools. Three departments of education and training of three provinces requested the program to provide STEM trainings to all teachers in their province. Although only 1,530 teachers were invited to the program's trainings, more than 15,000 teachers are active users of the online STEM platform every day. SESDP II gives priority of access to STEM education to ethnic minorities, remote and rural populations, females, and disabled groups.

\section{Implications for the Future}

The key to improving quality is the introduction of a new curriculum that is better attuned to the needs of economic development. MOET is already developing a competency-based curriculum that has the potential to better meet the needs of the workplace and society. However, MOET has not succeeded as yet in introducing the last new curricula. It will need to introduce professional development models, which go beyond the ineffective cascade model of teacher in-service, which merely transfers knowledge, to other models that change teacher behavior in the classroom. Models such as coaching/mentoring and community of practice have a larger potential to impact teachers. Changes in teacher and student assessments should also be a part of the new teaching and learning reforms. Viet Nam has made excellent progress in developing a teacher assessment system based on national professional standards, but it now needs to unify that system with the professional development of teachers.

The NER in primary and lower secondary education is close to reaching the targets, but enrollment in LSE and USE has dropped. Several recommendations suggest either

\footnotetext{
22 taphuan.sesdp2.edu.vn.
} 
removing barriers to transition or encouraging students and their parents to enroll in USE. The current elitist system of requiring students to graduate from LSE and pass an entrance examination to enroll in USE is restricting the number of students who can enroll. Some parents and students do not see the relevance of USE to future employment. Hopefully, the new curriculum and efforts to introduce career and vocational orientation will help address this perceived lack of relevance, but other strategies will likely be required such as making vocational education more appealing to students and their parents. Programs such as conditional cash transfers have been shown to increase enrollments by reducing the lost opportunity cost associated with attending, particularly among students from poor families such as those of ethnic minorities. An increase in USE enrollment will require more classroom space. As MOET has had difficulty in allocating funds for capital improvements, it will need to find alternative means such as using public-private partnerships to finance classroom improvements. Also, MOET needs to examine alternative cost-effective methods of delivering education, particularly in remote areas.

Links to the presentation materials: https://events.development.asia/materials/202 00528/pisa-2012-vietnam-results-and-lessons-learned.

\section{References}

Asian Development Bank (ADB). (2011). Project completion report: Upper secondary education development project in Viet Nam. Manila.

Department of Planning and Finance, MOET. (2015). Ha Noi.

Government of Viet Nam, Ministry of Education and Training, Center of Education Quality Assurance. (2016). Results from the National Achievement Monitoring. Ha Noi.

General Statistics Office (GSO). (2017). Labor Force Survey Q1 2017. Ha Noi.

Government of Viet Nam. (2010). Socio-Economic Development Strategy, 2011-2020. Ha Noi. Central Committee of the Communist Party of Viet Nam. 2013. Resolution No. 29-NQ/TW 8 on Comprehensive Innovations of Education and Training. Ha Noi.

Government of Viet Nam. (2012). Education development strategy, 2011-2020. Ha Noi.

Government of Viet Nam. (2014). Prime Minister's Resolution No. 44/NQ-CP on Radical Changes in Education and Training. Ha Noi. Government of Viet Nam. MOET. 2014. Minister of Education Decision No: 2653/QD-BGDĐT Action Plan of the Education Sector for the Implementation of Resolution No. 29. H Ha Noi.

Margot, K. C., \& Kettler, T. (2019). Teachers' perception of STEM integration and education: A systematic literature review. International Journal of STEM Education, 6(1), 2.

OECD. (2016). PISA 2015 results (volume I): Excellence and equity in education. Paris: OECD.

Tsupros, N., Kohler, R., \& Hallinen, J. (2009). STEM Education: A Project to Identify the Missing Components. Pennsylvania.

University of Oxford, Young Lives. (2017). Thinking outside the box: Do students in Vietnam have 21 st century skills? Retrieved September 11, 2017, from https://www.younglives.org.uk/content/ thinking-outside-box-do-students-vietnam-have-21st-century-skills..

Viet Nam National Institute of Education Sciences. (2010). Assessment of quality of upper secondary curriculum and textbooks. Ha Noi.

World Economic Forum. (2018). Global competitiveness report 2017-2018. Switzerland. 
World Development Indicators, World Bank. Retrieved April 24, 2017, from http://data.worldbank. org/country/vietnam.

The views expressed in this Chapter are those of the authors and do not necessarily reflect the views and policies of the Asian Development Bank (ADB) or its Board of Governors or the governments they represent.

ADB does not guarantee the accuracy of the data included in this Chapter and accepts no responsibility for any consequence of their use. The mention of specific companies or products of manufacturers does not imply that they are endorsed or recommended by ADB in preference to others of a similar nature that are not mentioned.

By making any designation of or reference to a particular territory or geographic area, or by using the term "country" in this Chapter, ADB does not intend to make any judgments as to the legal or other status of any territory or area.

This work is available under the Creative Commons Attribution 3.0 IGO license (CC BY 3.0 IGO) https://creativecommons.org/licenses/by/3.0/igo/. By using the content of this Chapter, you agree to be bound by the terms of this license. For attribution, translations, adaptations, and permissions, please read the provisions and terms of use at https://www.adb.org/terms-use\#openac cess.

This CC license does not apply to non-ADB copyright materials in this Chapter. If the material is attributed to another source, please contact the copyright owner or publisher of that source for permission to reproduce it. ADB cannot be held liable for any claims that arise as a result of your use of the material.

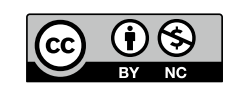

